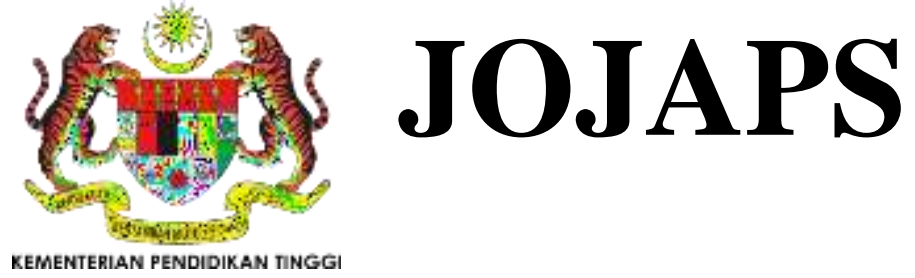

eISSN 2504-8457

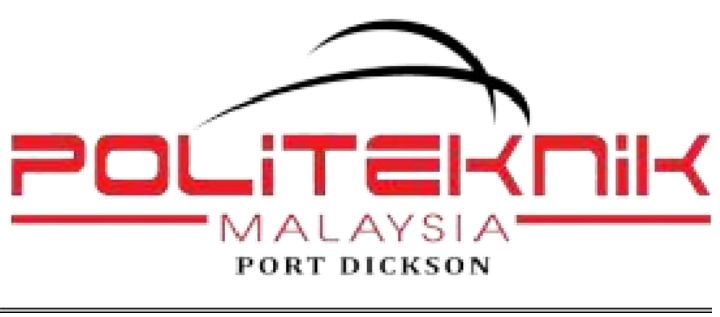

Journal Online Jaringan COT POLIPD

\title{
SWOT Analysis as Strategy to Improve Competitiveness of Durian Pancake Medium Enterprises
}

\author{
Suci Suci $^{\mathrm{a}}$, Dimas Ari Sanjaya ${ }^{\mathrm{a}}$, Iswandi Idris ${ }^{\mathrm{b}^{*}}$, Ruri Aditya Sari ${ }^{\mathrm{b}}$, Supriyanto Supriyanto ${ }^{\mathrm{a}}$ \\ \& Masniati Murni Ritonga ${ }^{\mathrm{c}}$ \\ ${ }^{a}$ Business Administration, Politeknik LP3I Medan, Indonesia \\ ${ }^{b}$ Industrial Engineering, Politeknik LP3I Medan, Indonesia \\ ${ }^{c}$ Computer Technology, Politeknik LP3I Medan, Indonesia
}

\begin{abstract}
One of the efforts that should be conducted by a businessman to compete in the global world is that understanding the situation and mastering market strategy. This study aimed to determine and analyze competitive strategies and improve competitive qualities contained based on SWOT analysis of strengths, weaknesses, opportunities and threats. This study conducted qualitative descriptive research. The data was obtained from observation, interview, and library study. The data were analysed based on IFAS matrix, EFAS matrix, SWOT diagram and SWOT Matrix. The results of this study indicate that durian pancake medium enterprise of SALINARY used product strategy and good service strategy to the customer. Business strategy was good enough but still need to do evaluation in more strategy to develop Durian pancake business. Based on SWOT Analysis, to improve the Quality of durian Pancake Business it was necessary to apply aggressive strategy or SO strategy. Therefore, Durian Pancake Enterprises could empower the opportunities to exist.
\end{abstract}

(C) 2012 Published by JOJAPS Limited.

Key-word: - SWOT, UKM, Marketing Strategy

\section{Introduction}

In the current era of globalization every medium enterprise would need a way to market their products indeed. Therefore it is important for small businesses to determine the strategies and steps being taken in order to maintain, promote and improve their business that is by using SWOT Analysis steps starting with the internal environment to know the factors of strengths and weaknesses of the company and the external environment to identify the factors of opportunity and threat firms. The level of success of a business in business competition can be seen from the ability of entrepreneurs in managing resources owned (Idris, 2017). In addition, product quality is also one important indicator for the company to be able to exist in the midst of competition in the industrial world (Ruri \& Fahmi, 2017). Armstrong (2005) states that good corporate performance has effectiveness in handling human resources, determining good targets must be achieved both organizationally and individually. If a person does not have the ability then the work of the resulting production does not increase well (Yolanda et al., 2018). Every company creates innovative and varied products with a strong brand in order to be known (Idris, 2018). Develop Small and Medium Enterprises digitally as a strategy in facing the era of Free Market (Slamet, R. 2016). The performance of SMEs tends to be better in terms of producing productive workforce (Widyatmini, I.D. and T.S., 2013). The use of effective SWOT analysis can play an important role in determining competitive strategy, in order to know the strengths, weaknesses, opportunities and threats faced by the company in maintaining the viability and continuity of the company (Nisak, 2013). 
According to Fahmi, Irham (2016) SWOT analysis can increase sales promotion, establish new more efficient strategies, improve product quality, improve product cost efficiency, and maintain and improve customer service. The results of the Cartesius diagram are in quadrant I. These quadrants support growth strategies, using the power to exploit any market opportunity (Suranta, 2015)

Furthermore, according to Fahmi, Irham (2014), the application of SWOT analysis on a company can provide a guide for the company to be more focused, so with the placement of SWOT analysis can be used as a comparison of thought from various angles, both in terms of strengths and weaknesses and opportunities and threats that may be biased in the future. Durian is a favorite fruit among the Asian community especially in Indonesia, North Sumatra is one of the areas that have a lot of durian, so very much the development of durian-based products produced in North Sumatra. Durian Pancake is one of dessert processed durian that people of Medan. One of the newly developed businesses include the category of small and medium enterprises or SMEs namely Pancake Durian. This Durian Pancake is made like Pancake in general just the contents of the pancake is the original fruit durian wrapped with cream and skin is very thin and soft. However, SME Pancake durian entrepreneurs must compete with Famous Restaurants in order to survive. Until now, the sales and production of SME Pancake durian is not very developed and advanced because this business has not known in detail what are the weaknesses and advantages of the products made as well as obstacles from outside parties that occur. This study aims to determine the business development strategy for SME Pancake Durian by using SWOT analysis

\section{Methodology}

This study was conducted in qualitative descriptive. It was studied at durian pancake Medan Tembung, Medan. The SWOT anlysis used the theory proposed by Rangkuti (2014).

IFAS Matrix (Internal Factor Analysis Summary)

The IFAS matrix (Table 1) is structured to formulate internal strategic factors into the framework of strength and weakness. The stages are as follows:

1. Column 1, determine the factors that become the strengths and weaknesses of the company.

2. Column 2, weight each of these factors on a scale ranging from 1.0 (most important) to 0.0 (unimportant), based on the influence of these factors on the firm's strategic position. (all weights can not exceed a total score of 1.00).

3. Column 3, calculate the rating for each factor by providing a scale ranging from 4 (outstanding) to 1 (poor), based on the influence of these factors on the condition of the company concerned. Positive variables (all variables included in power category) are scored from +1 to +4 (very good) by comparing them with the industry average or with the main competitor.

Rating Criteria:

a. Less good $=1$

b. Good enough $=2$

c. Good $=3$

d. Very good $=4$

4. Column 4, multiply the weights in column 2 with ratings in column 3, to obtain the weighting factor in column 4 . The result is that weighted score for each factor whose value varies from 4.0 (outstanding) to 1.0 ( poor).

5. Add the weighting score (in column 4), to get the total weighted score for the company in question. This total value shows how a particular company reacts to its internal strategic factors. This total score can be used to compare this company with other companies in the same industry group.

After the Internal strategic factors of a company are identified, an IFAS (Internal Factor Analysis Summary) table is structured to formulate internal strategic factors within the framework of Company Strength and Weaknesses. 
Table 1. IFAS (Internal Factor Analysis Summary)

\begin{tabular}{llccc}
\hline $\begin{array}{c}\text { Internal Strategies } \\
\text { Factors }\end{array}$ & Weight & Grade & Weight x Grade \\
\hline & Strengths: & & & \\
1. & $\ldots \ldots$ & 0,00 & 0 & 0,00 \\
2. & $\ldots \ldots$ & 0,00 & 0 & 0,00 \\
3. & $\ldots \ldots$ & 0,00 & 0 & 0,00 \\
4. & $\ldots \ldots$ & 0,00 & 0 & 0,00 \\
5. & $\ldots \ldots$ & 0,00 & 0 & 0,00 \\
\hline \multicolumn{2}{c}{ Weakness: } & 0,00 & 0 & 0,00 \\
1. & $\ldots \ldots$ & 0,00 & 0 & 0,00 \\
2. & $\ldots \ldots$ & 0,00 & 0 & 0,00 \\
3. & $\ldots \ldots$ & 0,00 & 0 & 0,00 \\
4. & $\ldots \ldots$ & 0,00 & 0 & 0,00 \\
5. & $\ldots \ldots$ & 0,00 & & 0,00 \\
\hline
\end{tabular}

Source: Rangkuti (2014)

\section{Matriks EFAS (Eksternal Factor Analysis Summary)}

The EFAS Matrix (Table 2) is structured to formulate external strategic factors into the opportunities framework and threats. The stages are as follows:

1. Column 1, identification of 5 - 10 kinds of opportunities and threats that have been analyzed.

2. Column 2, weight each factor, ranging from 1.0 (very important) to 0.0 (not important). These factors are likely to have an impact on strategic factors.

3. Column 3, calculate the rating for each factor by providing a scale ranging from 4 (outsanding) to 1 (poor) based on the influence of these factors on the condition of the company concerned. Rating rating for opportunity factor is positive (bigger chance given +4 rating, but if opportunity gets smaller given +1 branch). The rating of a threat rating is the reverse. The greater the threat the rating is 1 and vice versa, if the smaller the threat then the rating is 4 .

Rating Criteria:

a. Less good $=1$

b. Good enough $=2$

c. Good $=3$

d. Very good $=4$

4. Column 4, multiply the weights (column 2) by rating (column 3 ) to obtain the weighting factor. The result is a weighted score for each factor whose value varies from 4.0 (outstanding) to 0.1 (poor).

5. The number of weighted scores (column 4) to obtain a weighted score for the company concerned. This total value shows how a particular company reacts to its external strategy factors. This total score can be used to compare companies with one company in the same industry group.

Once the External strategic factors of an enterprise are identified, an EFAS table (External Factor Analysis Summary) is structured to formulate the External strategic factors within the Opportunities and Threaths framework of the firm. 
Table 2. EFAS (Eksternal Factor Analysis Summary)

\begin{tabular}{|c|c|c|c|}
\hline $\begin{array}{l}\text { External strategies } \\
\text { factors }\end{array}$ & Weight & Grade & Weight x Grade \\
\hline Opportunity: & & & \\
\hline 6. $\quad \ldots \ldots$ & 0,00 & 0 & 0,00 \\
\hline 7. $\quad \ldots \ldots$ & 0,00 & 0 & 0,00 \\
\hline 8. $\quad \ldots \ldots$ & 0,00 & 0 & 0,00 \\
\hline 9. $\quad \ldots \ldots$ & 0,00 & 0 & 0,00 \\
\hline $10 . \ldots \ldots$ & 0,00 & 0 & 0,00 \\
\hline Threats: & & & \\
\hline 6. $\quad \ldots \ldots$ & 0,00 & 0 & 0,00 \\
\hline 7. $\quad \ldots \ldots$ & 0,00 & 0 & 0,00 \\
\hline 8. $\quad \ldots \ldots$ & 0,00 & 0 & 0,00 \\
\hline 9. $\quad \ldots \ldots$ & 0,00 & 0 & 0,00 \\
\hline $10 \ldots \ldots$ & 0,00 & 0 & 0,00 \\
\hline Total & 0,00 & & 0,00 \\
\hline
\end{tabular}

Source: Rangkuti (2014)

\section{Results and Discussion}

\section{SWOT Data (Strengths, Weaknesses, Opportunities, Threaths)}

Application of SWOT Analysis on SME Pancake Durian done with the first author gives explanation tntang function and purpose of SWOT Analysis. This is done because previously Pancake durian SMEs never use a particular analysis to formulate or use strategies that will be used to face competition in the market

\section{1. (Strengths)}

It is the positive internal factors that contribute to the ability of this Durian Pancake SME to achieve its goals. These factors include:

a. Durian pancakes that are produced have a soft texture and skin tenderness to be more enjoyable forconsumption.

b. The ingredients of the composition are made from natural ingredients and are easy to obtain.

c. Selling Durian Pancakes with variant variant

d. Always give a special price for resellers and for the purchase of ecer the price is relatively affordable (cheap) and quality.

e. Products sold are always maintained khualitasnya, and has a characteristic that can compete with similar businesses.

f. Receive ordering service with wholesales and small parties

g. Cooperation and good communication of the owner with his employees.

These seven Strengths factors that will create the SO Strategy (Strengths Opportunities) also known as the Growth Oriented Strategy and the ST Strategy (Strengths Threaths) are the Diversification Strategies (Products / markets).

2. Weaknesses

These are the negative factors that reduce the ability of Pancake Durian SMEs to achieve their goals. These factors include:

a. Durian pancakes that can not last long outside the freezer and can only last 4-5 hours outside in freezing conditions.

b. Do not have a business license yet.

c. Do not have a systematic financial report.

d. Less promotion.

e. Limited number of work members.

f. Requires a large capital to develop this business.

These six Weaknesses will create a WO Strategy (Weaknesses Opportunities) also known as Turn-Around and WT

Strategy (Weaknesses Threaths) which is a Defensive Strategy (defense). 
3. Opportunities

These are positive External factors that can be utilized by this Durian Pancake SME to achieve its goals. These factors include:

a. Use of technology as a promotional tool to increase sales.

b. Many people love new names and foods.

c. Getting credit from Banks that give credit to SMEs.

d. The number of durian pancake enthusiasts as snacks and souvenirs.

e. Opening shop or café that dominated durian strategic location.

f. Getting new customers who are potentially loyal customers.

g. Increase promotion.

h. Have a creative workforce to create new products.

The eight Opportunities will create the SO (Strengths Opportunities) strategy, also known as the Growth Oriented Strategy and the WO Strategy (Weaknesses Opportunities) also known as the Turn-Around Strategy.

4. Threats (Threaths)

These are the negative External factors that hinder the ability of this Durian Sci Pancake SME to achieve its goals.

These factors are among others:

a. Unstable raw material prices.

b. Price competition between similar businesses.

c. Losing Pelnggan due to move to competitors.

d. Changes in consumer tastes.

e. Increased sales as population growth continues to increase.

f. New businessman who opened a similar business.

These six threatening factors (Threaths) that prevent them from dealing with the competition, will create the ST (Strengths Threaths) strategy also known as the Diversification strategy (Product / market) and the WT (Weaknesses Threaths) strategy, also known as Defensive strategy (persistence) .

IFAS Matrix (Internal Factor Analysis Summary)

Once the internal strategic factors of an enterprise are identified, an IFAS table (Table 5) is structured to formulate these internal strategic factors within the Company's Strength and Weakness framework as follows: 1. Column 1, determine the factors that become the strengths and weaknesses of the company. 2. Column 2, weight each of these factors on a scale ranging from 1.0 (most important) to 0.0 (unimportant), based on the influence of these factors on the firm's strategic position (all weights can not exceed a total score of 1.00).

4. Column 3, calculate the rating for each factor by providing a scale ranging from 4 (outstanding) to 1 (poor), based on the influence of these factors on the condition of the company concerned. Positive variables (all variables included in power category) are scored from +1 to +4 (very good) by comparing them with the industry average or with the main competitor. While the variable is negative, the opposite.

Rating Criteria:

a. Less $\operatorname{good}=1$

b. Good enough $=2$

c. Good $=3$

d. Very good $=4$

4. Column 4, multiply the weights in column 2 with ratings in column 3 , to obtain the weighting factor in column 4 . The result is a weighted score for each factor whose value varies from 4.0 (outstanding) to 1.0 (poor). Add the weighting score (in column 4), to get the total weighted score for the company in question. This total value shows how a particular company reacts to its internal strategic factors. This total score can be used to compare this company with other companies in the same industry group (Table 3) 
Table 3. Weighting internal factors

\begin{tabular}{|c|c|c|c|}
\hline \multirow{2}{*}{$\begin{array}{c}\text { Factors } \\
\text { Production }\end{array}$} & \multicolumn{3}{|c|}{ Influence } \\
\hline & Symbol & Score & Weight \\
\hline $\begin{array}{l}\text { a. Durian pancakes have a soft texture tenderness and a } \\
\text { thinner skin to make it more enjoyable to eat. }\end{array}$ & $\mathbf{S}$ & 4 & $\mathbf{0 , 0 8}$ \\
\hline $\begin{array}{l}\text { b. Products sold are always maintained khualitasnya and has } \\
\text { a characteristic that can compete with similar businesses. }\end{array}$ & $\mathbf{S}$ & 4 & 0,08 \\
\hline $\begin{array}{l}\text { c. Durian pancakes that can not last long outside the freezer } \\
\text { and can only last } 4-5 \text { hours outside in freezing conditions. }\end{array}$ & $\mathbf{W}$ & 3 & 0,06 \\
\hline $\begin{array}{l}\text { d. The ingredients of the composition are made from natural } \\
\text { ingredients and are easy to obtain. }\end{array}$ & $\mathbf{S}$ & 4 & $\mathbf{0 , 0 8}$ \\
\hline $\begin{array}{l}\text { e. Receive ordering service with wholesales and small } \\
\text { parties. }\end{array}$ & $\mathbf{W}$ & 4 & 0,08 \\
\hline f. Limited number of work members. & $\mathbf{S}$ & 4 & 0,08 \\
\hline g. does not yet have a business license. & $\mathbf{W}$ & 4 & $\mathbf{0 , 0 8}$ \\
\hline $\begin{array}{l}\text { Financial } \\
\text { a. do not have a systematic financial statement. } \\
\text { b Requires venture canital to exnand this business }\end{array}$ & $\mathbf{W}$ & 4 & $\mathbf{0 , 0 8}$ \\
\hline${ }^{1}$ & $\mathbf{W}$ & 4 & 0,08 \\
\hline $\begin{array}{l}\text { a. Selling durian pancakes with variant variants. } \\
\text { b. Always give a special price for resellers and for the }\end{array}$ & $\mathbf{S}$ & 3 & 0,06 \\
\hline $\begin{array}{l}\text { purchase of ecer the price is relatively affordable (cheap) } \\
\text { and quality. } \\
\text { c. Less promotion }\end{array}$ & $\mathbf{S}$ & 4 & 0,08 \\
\hline & $\mathbf{W}$ & 4 & 0,08 \\
\hline $\begin{array}{l}\text { Human Resource } \\
\text { a. Good cooperation and communication between } \\
\text { employee and the owner. }\end{array}$ & $\mathbf{S}$ & 4 & 0,08 \\
\hline Total & & $\mathbf{5 0}$ & 1 \\
\hline
\end{tabular}

Note: $\mathrm{S}:$ Strong $\quad$ W : Weak 
Table 5. Matriks IFAS (Internal Factor Analysis Summary)

\begin{tabular}{|c|c|c|c|}
\hline Internal Factors & Weight & Grade & Weight x Grade \\
\hline $\begin{array}{l}\text { Strengthness } \\
\end{array}$ & & & \\
\hline $\begin{array}{l}\text { a. Durian pancakes that are produced have a } \\
\text { soft texture and skin tenderness to be more } \\
\text { enjoyable for consumption. }\end{array}$ & $\mathbf{0 , 0 8}$ & 4 & $\mathbf{0 , 3 2}$ \\
\hline $\begin{array}{l}\text { b. The ingredients of the composition are made } \\
\text { from natural ingredients and are easy to obtain. } \\
\text { c. Selling Durian Pancakes with variant variant }\end{array}$ & $\mathbf{0 , 0 8}$ & 2 & $\mathbf{0 , 1 6}$ \\
\hline $\begin{array}{l}\text { d. Always give a special price for resellers and } \\
\text { for the purchase of ecer the price is relatively }\end{array}$ & $\mathbf{0 , 0 6}$ & 3 & $\mathbf{0 , 1 8}$ \\
\hline $\begin{array}{l}\text { affordable (cheap) and quality. } \\
\text { e. Products sold are always maintained } \\
\text { khualitasnya, and has a characteristic that can } \\
\text { compete with similar businesses. }\end{array}$ & $\mathbf{0 , 0 8}$ & 3 & 0,24 \\
\hline f. Receive ordering service with wholesales and & $\mathbf{0 , 0 8}$ & 3 & $\mathbf{0 , 2 4}$ \\
\hline small parties & $\mathbf{0 , 0 8}$ & 3 & 0,24 \\
\hline $\begin{array}{l}\text { g. Cooperation and good communication of the } \\
\text { owner with his employees. }\end{array}$ & $\mathbf{0 , 0 8}$ & 3 & $\mathbf{0 , 2 4}$ \\
\hline $\begin{array}{c}\text { Total of Strengthness } \\
\text { Weakness }\end{array}$ & $\mathbf{0 , 5 6}$ & & 1,62 \\
\hline $\begin{array}{l}\text { a. Pancake Durian cannot resist outside of } \\
\text { freezer and it take only } 5 \text { hours in freezing }\end{array}$ & 0,06 & 4 & $\mathbf{0 , 2 4}$ \\
\hline texture. & $\mathbf{0 , 0 8}$ & 4 & $\mathbf{0 , 3 2}$ \\
\hline b. No lisence of enterprise & $\mathbf{0 , 0 8}$ & 2 & 0,16 \\
\hline c. No systematically financial statement & & & \\
\hline d. Lack of promotion & $\mathbf{0 , 0 8}$ & 2 & $\mathbf{0 , 1 6}$ \\
\hline e. Limited numbers of employees & $\mathbf{0 , 0 8}$ & 3 & 0,24 \\
\hline f. Necessary much more capital & $\mathbf{0 , 0 8}$ & 3 & 0.24 \\
\hline Totalof weakness & 0.44 & & 1,36 \\
\hline
\end{tabular}
The different score between
strengthness and weakness

$1,62-1,36=0,26$

\section{Matriks EFAS (Eksternal Factor Analysis Summary)}

Once the external strategic factors of an enterprise are identified, an EFA table (Table 8) is structured to formulate external strategic factors as follows:

1. Column 1, identification of 5 - 10 kinds of opportunities and threats that have been analyzed.

2. Column 2, weight each factor, ranging from 1.0 (very important) to 0.0 (not important). These factors are likely to have an impact on strategic factors.

3. Column 3, calculate the rating for each factor by providing a scale ranging from 4 (outsanding) to 1 (poor) based on the influence of these factors on the condition of the company concerned. Rating rating for opportunity factor is positive (bigger chance given +4 rating, but if opportunity gets smaller given +1 branch). The rating of a threat rating is the reverse. The greater the threat the rating is 1 and vice versa, if the smaller the threat then the rating is 4 .

Rating criteria:

a. Less $\operatorname{good}=1$

b. Good enough $=2$

c. Good $=3$

d. Very good $=4$

Column 4, multiply the weights (column 2) by rating (column 3) to obtain the weighting factor. The result is a weighted score for each factor whose value varies from 4.0 (outstanding) to 0.1 (poor). 2. The number of weighted scores (column 4) to obtain a weighted score for the company concerned. This total value shows how a particular company reacts to its external strategy factors. This total score can be used to compare firms to other companies in the same industry group (Table 6). 
Table 6. Weighting external factors

\begin{tabular}{|c|c|c|c|}
\hline \multirow{2}{*}{$\begin{array}{l}\text { Factors } \\
\text { Production }\end{array}$} & \multicolumn{3}{|c|}{ Influence } \\
\hline & Symbol & Score & Weigh \\
\hline $\begin{array}{l}\text { a. Use of technology as a promotional tool to increase } \\
\text { sales. }\end{array}$ & $\mathbf{o}$ & 4 & $\mathbf{0 , 0 8}$ \\
\hline b. Unstable raw material prices. & $\mathbf{T}$ & 3 & 0,06 \\
\hline c. Price competition between similar businesses. & $\mathbf{T}$ & 4 & $\mathbf{0 , 0 8}$ \\
\hline d. Losing customer due to move to competitors. & $\mathbf{T}$ & 3 & 0,06 \\
\hline e. Changes in consumer tastes. & $\mathbf{T}$ & 4 & 0.08 \\
\hline $\begin{array}{l}\text { f. An increased sale as population growth continues } \\
\text { to increase. }\end{array}$ & $\mathbf{T}$ & 3 & $\begin{array}{l}0,00 \\
0,06\end{array}$ \\
\hline g. Bantaknya people love the name and new food. & $\mathbf{O}$ & 3 & 0,06 \\
\hline $\begin{array}{l}\text { Financial } \\
\text { a. Applaying credit from the bank that loan medium } \\
\text { enterprises }\end{array}$ & $\mathbf{O}$ & 4 & $\mathbf{0 , 0 8}$ \\
\hline Marketing & & & \\
\hline a. Plenty of pancake lovers as snack or presents & $\mathbf{O}$ & 3 & 0,06 \\
\hline $\begin{array}{l}\text { b. Establish a café or shop with durian holic in market } \\
\text { places }\end{array}$ & $\mathbf{O}$ & 4 & 0,08 \\
\hline $\begin{array}{l}\text { c. Inviting new cutomers those potential tobe loyal } \\
\text { customers } \\
\text { d. Business man who have similar business }\end{array}$ & $\mathbf{O}$ & 3 & 0,06 \\
\hline e. Increae promotion & $\mathbf{T}$ & 4 & $\mathbf{0 , 0 8}$ \\
\hline & $\mathbf{O}$ & 4 & $\mathbf{0 , 0 8}$ \\
\hline $\begin{array}{l}\text { Human Resource } \\
\text { a. Creative employe to create something new and } \\
\text { unique }\end{array}$ & $\mathbf{O}$ & 4 & $\mathbf{0 , 0 8}$ \\
\hline Total & & $\mathbf{5 0}$ & 1 \\
\hline
\end{tabular}

Note : O: Opportunity $\quad T:$ threat

Table 8. Matriks IFAS (Internal Factor Analysis Summary)

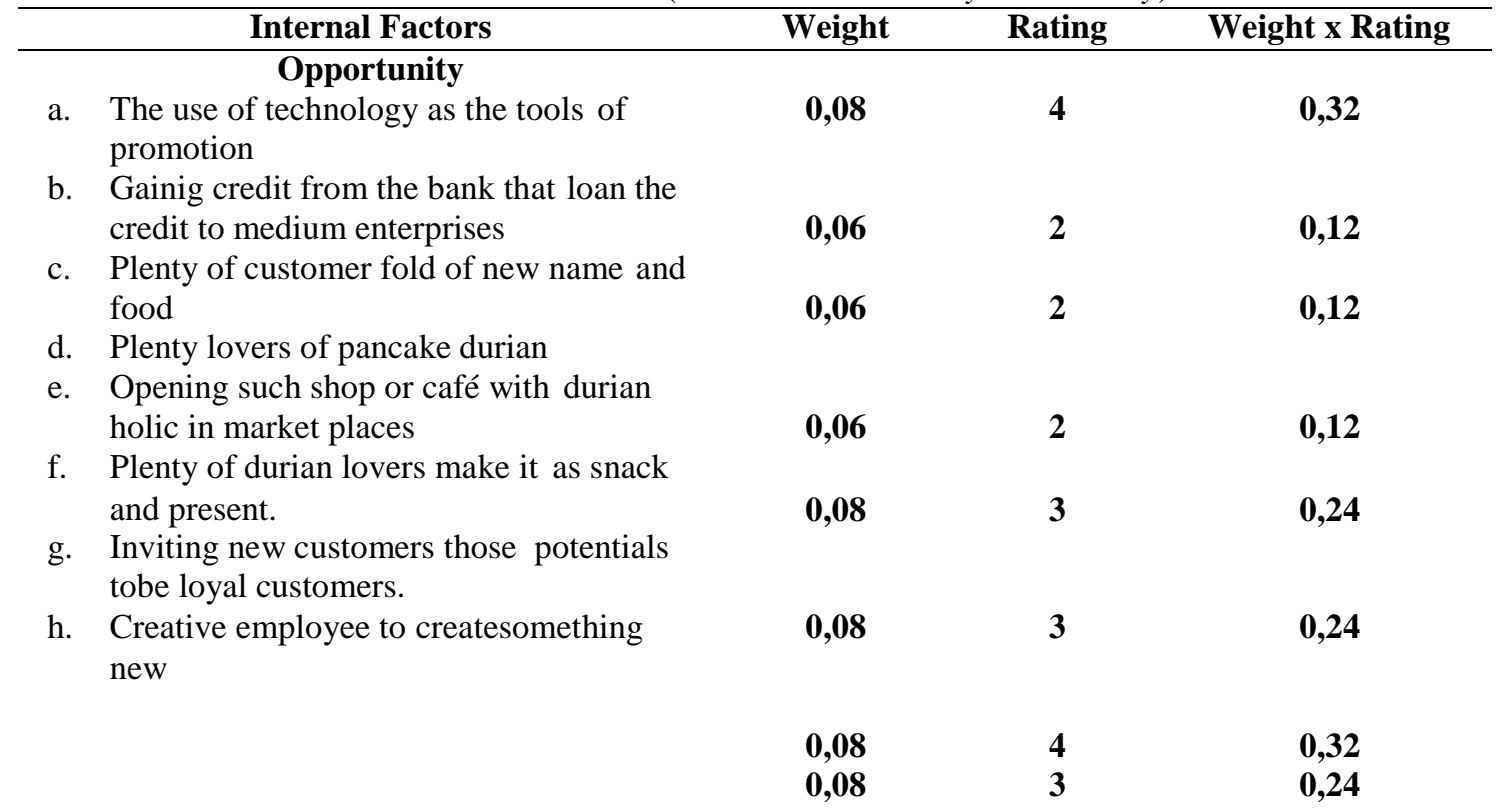




\section{Total strengthness}

Threat

a. Unstable price of ingredients

b. Price Competitiveness between similar business

c. Losing customers because the customers moved to competitors

d. Consumer's desire exchange

e. The increasing sale because the population keep growing

f. Businessman recent similar business $\mathbf{0 , 5 8}$

0,06

0,08

0,06

0,08

0,06

0,08
1,72

0,24

$\mathbf{0 , 3 2}$

0,18

0,24

0,18

0,24

Total weakness

0.42

1,4

Difference score between strengthness

and weakness

\section{Diagram SWOT}

Based on the analysis of IFAS matrix known total score factor strength gain result 1.62 whereas total score factor weakness 1.36. This shows that the strength factor of Durian pancake medium enterprise is greater than the weakness factor. Then based on analysis of EFAS Matrix known total factor score Opportunity get result 1,72 whereas total score factor of Threat get result 1,4. This indicates that the opportunity factor owned by Pancake Durian UKM is greater than the threat factor. Then it is known that the factors of strength and opportunities that have can support in this business purpose. Based on the above, the strategy to be taken by Durian pancake medium enterprise can be described in the SWOT diagram. Drawing a SWOT diagram requires an affirmation of the position of the end line between Strengths and Weaknesses as well as Opportunities and Threats that are all depicted in positive and negatife lines. This results in a total strength score of 1.62 while the total weakness score becomes -1.36 as well as the total fixed Opportunity score is 1.72 while the total Threat score becomes -1.4. Here is a SWOT Pancake Durian SWOT diagram with the result of internal analysis comparison (Strength and Weakness) with external analysis (Opportunity and Threat) :

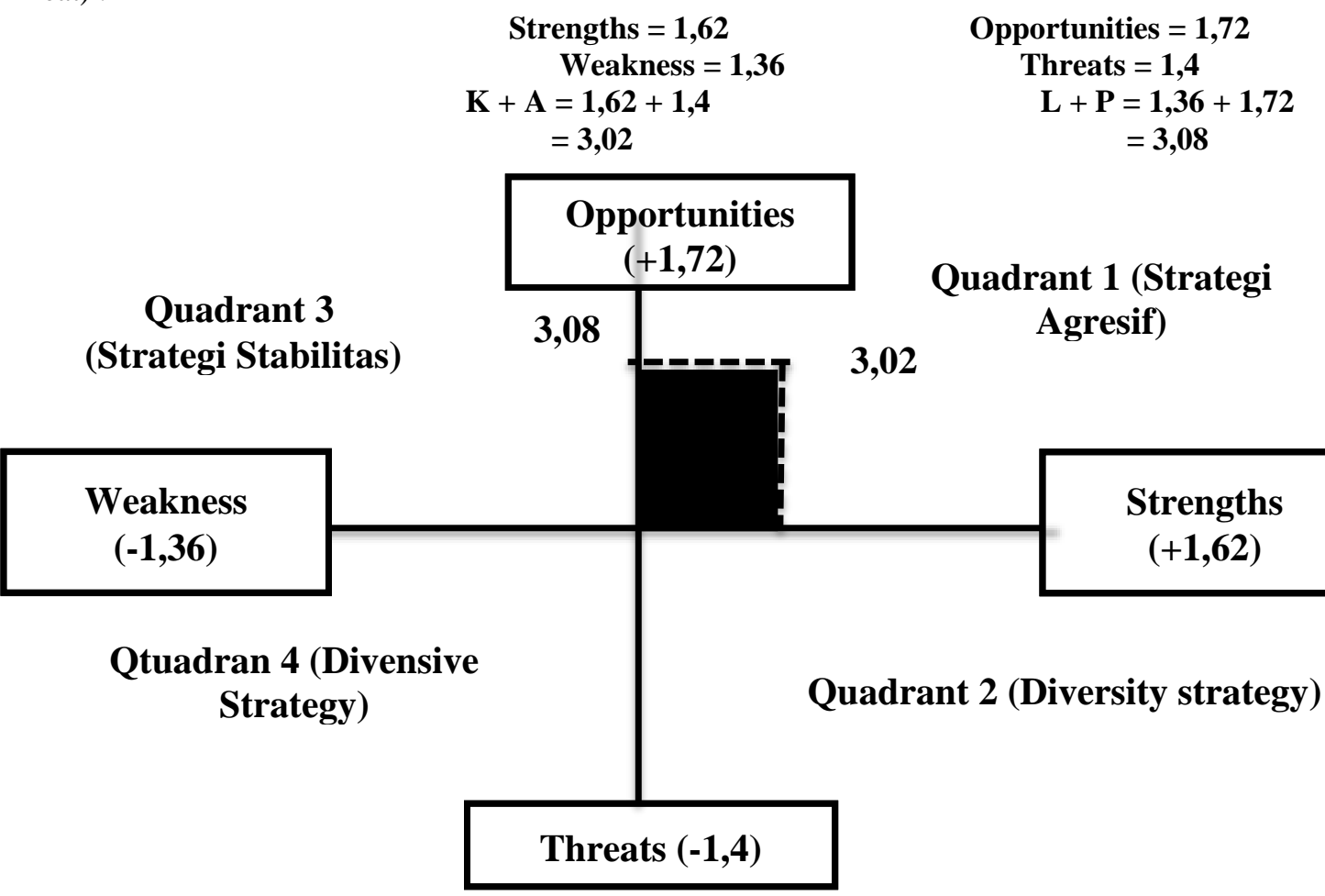

Figure 1. SWOT Analysis Durian Pancake Enterprise 
From the results of data analysis obtained, it can be seen that Durian pancake medium enterprise is located in Quadrant I (Aggressive). Where it has a good weight value in the internal environment at Strength (Strenght) position is aggressively aggressive and the weight of value in its external environment is good in Oppoerunities position. So it can be concluded that the position of Durian pancake enterprise competition according to the SWOT diagram is in the first quadrant (Aggressive), which indicates the company has opportunities and the number of forces that encourage the use of those opportunities.

SWOT Matrix Analysis

Through applying this SWOT matrix analysis, it is easier the company to improve its good strategy based on the combination of internal and external factors. The SWOT matrix will generate alternative SO strategies, WO, ST, WT. Table 9 shows the SWOT matrix of Durian Pancake.

Table 9. Matriks SWOT

(Strength)

a. Durian pancakes that are produced have a soft texture and skin tenderness to be more enjoyable for consumption.

b. The ingredients of the composition are made from natural ingredients and are easy to obtain.

c. Selling Durian Pancakes with variant variant d. Always give a special price for resellers and for the purchase of ecer the price is relatively affordable (cheap) and quality.

e. Products sold are always maintained khualitasnya, and has a characteristic that can compete with similar businesses.

f. Receive ordering service with wholesales and small parties

g. Cooperation and good communication of the owner with his employees.
(Opportunities)

a. The use of technology as the tools of promotion

b. Gainig credit from the bank that loan the credit to medium enterprises

c. Plenty of customer fold of new name and food

d. Plenty lovers of pancake durian

e. Opening such shop or café with durian holic in market places

f. Plenty of durian lovers make it as snack and present.

g. Inviting new customers those potentials tobe loyal customers.

h. Creative employee to createsomething new

\section{$\underline{\text { SO Strategies }}$}

1. Maintaining the soft texture of durian pancake in order to attract customers' consumption.

2. Cheaper price would take customers' interest

3. Strengthen the commitment between customers and owner

4. Innovate durian pancake to be more varies and eye cathes

5. Propose credit bank to the bank that loan money to medium enterprises

\section{(Weaknesses)}

a. Pancake Durian cannot resist outside of freezer and it take only 5 hours in freezing texture.

b. No lisence of enterprise

c. No systematically financial statement

d. Lack of promotion

e. Limited numbers of employees

f. Necessary much more capital

\section{(Opportunities)}

a. The use of technology as the tools of promotion

b. Gainig credit from the bank that loan the credit to medium enterprises

c. Plenty of customer fold of new name and food

d. Plenty lovers of pancake durian

e. Opening such shop or café with durian holic in market places

f. Plenty of durian lovers make it as snack and present.

g. Inviting new customers those potentials tobe loyal customers.

h. Creative employee to createsomething new 


\section{WO strategy}

1. Create longer resisted durian pancake without preservative, yet healthy ingredients since durian pancake beoming one of snack and presents

2. Create systematically financial statement

3. Using sophisticated technology in operating durian pancake enterprise.

4. Compiling the license to local government

\section{(Strength)}

a. Durian pancakes that are produced have a soft texture and skin tenderness to be more enjoyable for consumption.

b. The ingredients of the composition are made from natural ingredients and are easy to obtain.

c. Selling Durian Pancakes with variant variant d. Always give a special price for resellers and for the purchase of ecer the price is relatively affordable (cheap) and quality.

e. Products sold are always maintained khualitasnya, and has a characteristic that can compete with similar businesses.

f. Receive ordering service with wholesales and small parties

g. Cooperation and good communication of the owner with his employees.

\section{(Threarts)}

a. Unstable price of ingredients

b. Price Competitiveness between similar business

c. Losing customers because the customers moved to competitors

d. Consumer's desire exchange

e. The increasing sale because the population keep growing

f. Businessman recent similar business

\section{ST strategies}

1. Cheaper price did not defeat the character of this durian pancake with other competitors

2. Empowering the cooperation between members and owner

3. Cooperate with th ingredients' distributor

\section{(Weaknesses)}

a. Pancake Durian cannot resist outside of freezer and it take only 5 hours in freezing texture.

b. No lisence of enterprise

c. No systematically financial statement

d. Lack of promotion

e. Limited numbers of employees

f. Necessary much more capital

\section{WT Strategies}

1. Engage good relation to the customers

2. Maintaining the special character of its product

3. Mastering culinary enterprises (durian pancake

\section{(Threarts)}

a. Unstable price of ingredients

b. Price Competitiveness between similar business

c. Losing customers because the customers moved to competitors

d. Consumer's desire exchange

e. The increasing sale because the population keep growing

f. Businessman recent similar business

g.

\section{SWOT Stratehies of Durian Pancake enterprise}

1. SO (Strengths Opportunities) Strategies

a. Maintaining the softness texture of durian pancake for more consumers in consuming durian pancakes. To keep customers from moving to similar businesses, durian pancake enterprises have to maintain the softness texture to strengthen and attract customers' intention.

b. Cheap prices would be the spotlight of durian lovers. Due to the number of durian lovers in Indonesia resulted a lot of consumers' demand for durian, as the processed food and fruit interact, then the price becomes the main focus. Durian Pancake sellers are competing to provide a low price for resellers. Although it slightly reduces profits, it can be profitable in the long term. 
c. Strengthen commitment between owner and customer. The most important asset in a large company, as well as a small company is the customer. Therefore, every company will establish cooperation among its loyal customers who always help it to keep growing. Due to the increasingly fierce business competition, owner established good communication with the customers in order to create a sense of convenient subscription, so from customers do not turn to other manufacturers, where the owner always meet the needs of customers and customers also receive well what is given so that mutual benefit other.

d. Innovate to create a durian pancake menu that has a unique and funny contents variant. Diversity of the size of the existing Durian Pancake form this business can be maximized by adding new menus such as color and size of pancakenya different and more diverse. For example rainbow durian pancakes and belaster with a blend of beautiful colors and bright make customers continue to be interested to buy it. Durian enterprise must be able to keep together and keep communicating well with its employees in terms of creating new menu. The innovation can be a product favorite that customers like.

\section{ST (Strengths Threaths) Strategies}

a. The price does not make this durian pancake taste inferior to other durian pancakes. Price is a major factor in a trade. Strategies owned by the owner to create an advantage in the business is to provide a cheap price and quality. Due to the many sellers of fake durian pancakes in the trading market by giving less good quality. However, durian pancake enterprise continue to give the same taste with in producing durian pancake because the ingredients and composition are always the same every making is not changing then the quality given remains the same and no less delicious with other durian pancakes.

b. Increase cooperation on owners and members. One important asset in a company is a member of the worker who helps the owner to resize his work. In order to get a better quality by creating a sense of empowerment between employee and owner in producing durian pancakes. in this durian pancake business can be seen that there is no limit between the owner and the worker, even the owner was always involved in making pancake durian in order to achieve the target according to the order.

c. Working closely with raw material suppliers. Food business especially Pancake Durian sometimes faced with constraints in meeting the need for raw materials as well as unstable prices. To face the problem, durian pancake medium enterprises must establish good relationship with raw material suppliers, because it is very useful for durian pancake business in terms of meeting the availability of raw materials and for durian pancake medium enterprise itself with a good relationship with raw material suppliers can easily obtain information regarding the price and availability of the tray from the supplier itself.

\section{WO (Weaknesses Opportunities) Strategies}

a. Creating durian pancake production in order to survive longer by not using preservatives but natural ingredients, because the pancakes are produced as a souvenir snack. Durian pancakes that can not last long outside the freezer (freezer), due to durian that can not last long, therefore durian pancake medium enterprise have to make sense to durian pancakes can last long to be an advantage in the business and customers who buy not worry anymore acid or stale durian if the pancake is out too long and can be taken for long trips without having to be complicated to be picked up.

b. Create a systematic financial report. The weakness of Medium Enterprises in general is the absence of systematic financial statements, so the owner does not know exactly the amount of income and expenditure from business operations. This is also the case with durian pancakes. Durian pancake medium enterprise has financial statement in book form which records transaction which happened to its business, but the report has not been made completely, rapid and systematic. The financial statements are still very simple form of Pancake durian income obtained from the purchase and ordering.

c. Using emerging technologies for operational activities in durian pancakes. Technology is currently growing rapidly and has a role in supporting business activities. With existing technology durian pancake medium enterprise can make brochures or Brenner for promotional activities durian pancakes. In addition to preparing financial statements can also be done by using a computer to more rapidly systematic.

d. Take care of business license to local government. The sustainability of a business is also influenced by the existence of the legality element of the business. In an attempt the legality factor is manifest in the ownership of business licenses. By having a business license, the business activities undertaken will provide a sense of security and comfort for the sustainability of their business. Benefits derived from the ownership of these licenses are as a means of legal protection.

\section{WT (Weaknesses Threaths) Strategies}

a. Establish good relationships with customers. For large companies as well as small companies the most important asset is the customer. Therefore every company will give the best service for all customers. In Accordance with the increasingly tight business competition. Durian pancakes should be able to provide the best service and products for their customers to keep their customers loyal. Losing potential customers is a big problem for durians pancake medium enterprise, because the presence of durian pancakes is strongly influenced by customers' willingness to buy. 
To establish good relationships with customers is to make customers feel well served, friendly and full of patience. Such small concerns will lead to customer satisfaction.

b. Maintaining product quality and product characteristics. To keep customers from moving to similar businesses, durian pancake medium enterprise must maintain the cleanliness and taste quality of the durian pancakes they sell. In addition SME Pancake durian should highlight what is the hallmark of other similar business products. It aims to keep customers loyal to durian pancakes.

c. Mastering the culinary business (Pancake Durian). with increasingly fierce competition, the constraints that arise in culinary business and the increasingly global market conditions, Durian pancake medium enterprise are required to be able to fight the increasingly intense competition. Durian pancake medium enterprise must deepen the field of food business especially durian pancake, looking for new products, culinary business information, knowing good business management and other things related to the business. To get the information, Durian pancake medium enterprise can read books and internet. Extensive knowledge will make durian pancake medium enterprise able to face competition and also innovate on strategies that have been implemented so far. In addition the existence of durian Pancake business survived, although many new competitors are emerging.

\section{Conclusion}

Based on the results of research conducted by the author, it could be concluded that, from the results of data analysis obtained, can be seen that durian pancake Medium Enterprise lies on Quadrant I (Aggressive). It shows that it has a good score in the internal environment in the position of strength (strength) in aggressive Quadrant and good score in external environment in the position of opportunities (opportunities). Therefore it can be concluded that the position of Durian Pancake enterprise competition according to the SWOT diagram is in the first quadrant (Aggressive) which indicates this company has the opportunity and the number of forces that encourage the use of these opportunities. There are some strategies could be conducted by durian pancake medium enterprise through SWOT Analysis, such as:

a. Applying for loans to banks that give credit to medium enterprise to increase the company's capital so that if many customers who order in large quantities (party) the company is able to meet these reservations at once provide a special price cheaper than the purchase price of the unit so that distributors and resellers can sell durian pancakes according to market price.

b. Innovate to create a new menu of unique and interesting durian base materials.

c. Creates durian pancakes to last longer when outside freezer.

\section{References}

Agustina, I., \& Arfan, M. (2015). Pengaruh Set Peluang Investasi Dan Financial Leverageterhadap Return Saham Yang Dimediasi Oleh Manajemen Laba (Studi Pada Perusahaan Manufaktur Periode 2010-2013 yang Terdaftar di Bursa Efek Indonesia). Jurnal Administrasi Akuntansi: Program Pascasarjana Unsyiah, 4(3).

Idris, I., Hasibuan, H., Efriza, D., \& Sari, R. A. (2017). IbM Peningkatan Produktivitas Kelompok Usaha Roti "Nenot-Nenot" Kelurahan Suka Ramai Medan. Jurnal Teknovasi: Jurnal Teknik dan Inovasi, 4(1), 51-58.

Ruri, A., S., \& Fahmi, S., (2017). “Analisis Peningkatan Kualitas Produk Keramik dengan Menggunakan Metode Six Sigma di CV. Gunung Mas Medan”, Jurnal Teknovasi, 4(1), 70-78.

Yolanda, A., Ranita, S. V., Idris, I., \& Nurismilida, N. (2018). Efektivitas Penilaian Prestasi Kerja Karyawan (Studi Kasus: PTPN IV (Persero)-Kebun Tinjowan Simalungun). Jurnal Bis-A: Jurnal Bisnis Administrasi, 4(2), 69-74.

Idris, I., Hanum, Z., \& Wahyudi, D. (2018). Analisis Ekuitas Merek Ponsel Samsung Sebagai Usulan Untuk Membidi Lismaita, L., \& Liyudza, L. (2018). Analisis Biaya Agensi Pada Perusahaan Manufaktur Yang Terdaftar Di Bursa Efek Indonesia. Jurnal Bis-A: Jurnal Bisnis Administrasi, 7(2), 29-32.

Segmentasi Baru Di Kota Medan. Jurnal Bis-A: Jurnal Bisnis Administrasi, 4(2), 75-78.

Slamet, R. et al., 2016. Strategi Pengembangan UKM Digital dalam Menghadapi Era Pasar Bebas. Jurnal Manajemen Indonesia, 16(2), pp.136-147. Available at: http://journals.telkomuniversity.ac.id/ijm/article/view/319.

Nisak, Z., 2013. Analisis Swot Untuk Menentukan Strategi Kompetitif. Ekbis, 9(2), p.8.

Fahmi, Irham. (2014). "Kewirausahaan Teori, Kasus, dan Solusi”, Cetakan Kedua, Bandung: Alfabeta, CV.

Suranta, G.F., 2015. Analisis Strategi Pemasaran Jasa Menghadapi Pesaing. Analisis Strategi Pemasaran Jasa Menghadapi Pesaing, 1(1), pp.22-32.

Fahmi, Irham. (2016). “Teori Dan Teknik Pengambilan Keputusan”, Cetakan Kesatu, Jakarta: PT, Raja Grafindo Persada. Rangkuti, Freddy, (2014), “Analisis SWOT Teknik Membedakan Kasus Bisnis”, Cetakan Kedelapan Belas, Jakarta: PT,

Gramedia Pustaka Utama.

Amstrong, Micheal. (2005). "Manajemen Sumber Daya Manusia”, Jakarta: PT. Elexmedia Komputindo.

Wardayani, W., \& Wahyuni, D. S. (2018). Analisis Return on Asset, Current Ratio dan Debt Ratio dalam Menilai Kinerja Keuangan pada PT. Pelabuhan Indonesia I (Persero) cabang Belawan. Jurnal Ilman: Jurnal Ilmu Manajemen, 4(1). 